\title{
A New Model Cage for Simultaneous Measurements of Wheel-running and Ambulatory Activity in the Rat
}

\author{
Junji MIZOGUCHI and Tsuneo OHTAKI \\ Hatano Research Institute Food and Drug Safety Center, \\ 729-5 Ochiai, Hadano, Kanagawa 257, Japan.
}

(Received 30 June 1987/Accepted 29 September 1987)

\begin{abstract}
A new type of cage including a running wheel basket and tilting floor was developed. Using this cage it was possible to record simultaneously wheel-running and ambulatory activity of the rat.
\end{abstract}

There are various methods for measuring the motor activity of rats and mice, for example, running wheel cages $[3,4,6,8]$, induction coils [5], photo-cells [7] and flat floor cages $[1,2,9,10]$. Motor activity measured by these methods may be classified into two types: running activity in the running wheel cages and ambulatory activity in the flat floor cages. Numerous experiments on the motor activity of small rodents have been performed using the running wheel cage. However, it has been suggested that these two types of activity appear to differ in quality [10]. Recently, we recognized that estrogen administration enhanced the wheel-running activity in the rat but did not affect ambulatory activity. On the other hand, methamphetamine hydrochloride potentiated only ambulation (unpublished). Therefore, it is important to measure these two types of activity simultaneously. The present paper discusses a new type of cage whereby it is possible to measure both types of activity at the same time.

In the present experiment, three different kinds of cages were used: a running wheel cage for measuring wheel-running activity, an ambulo-drinko meter for measuring ambulatory activity, and a new type of cage developed by the authors for the simultaneous measurement of both types of activities. The running wheel cage (O'hara \& Co., Ltd., Tokyo Japan) included a wheel basket $(11.0(\mathrm{~W}), 29.0(\mathrm{O} . \mathrm{D}) \mathrm{cm})$ and resting cage $(23.0 \times 11.0 \times 13.0 \mathrm{~cm})$. Every time the wheel basket completes $1 / 3$ of a revolution, it is taken as one count. In the ambulodrinko meter (O'hara \& Co. Ltd., $20 \times 40 \times 25$ $\mathrm{cm}$ ), ambulatory activity is measured by a tilting floor which is supported by two steel beams [10]. The new cage is shown Figs. 1. and 2. The cage is composed of two parts: a running wheel basket $(9.0(\mathrm{~W}), 29.0(\mathrm{O} . \mathrm{D}) \mathrm{cm})$ and tilting floor cage $(11.0 \times 40.0 \times 26.0 \mathrm{~cm})$. An animal may enter both parts freely. With this setup, it is possible to record simultaneously wheel-running and ambulatory activity. Fifteen male $\mathrm{Crj}$ : $\mathrm{CD}$ (SD) rats, 8 weeks old and weighing $280-310 \mathrm{~g}$ (Charles River Japan Inc.), were used. The animals were housed individually in three different kinds of cages and allowed free access to a commercial diet (CE-2, CLEA Japan, Tokyo) and water. They were reared in a room with the temperature controlled at $25 \pm 1^{\circ} \mathrm{C}$, the relative humidity at $55 \pm 5 \%$ and the lights on from 7.00 to 19.00 . 


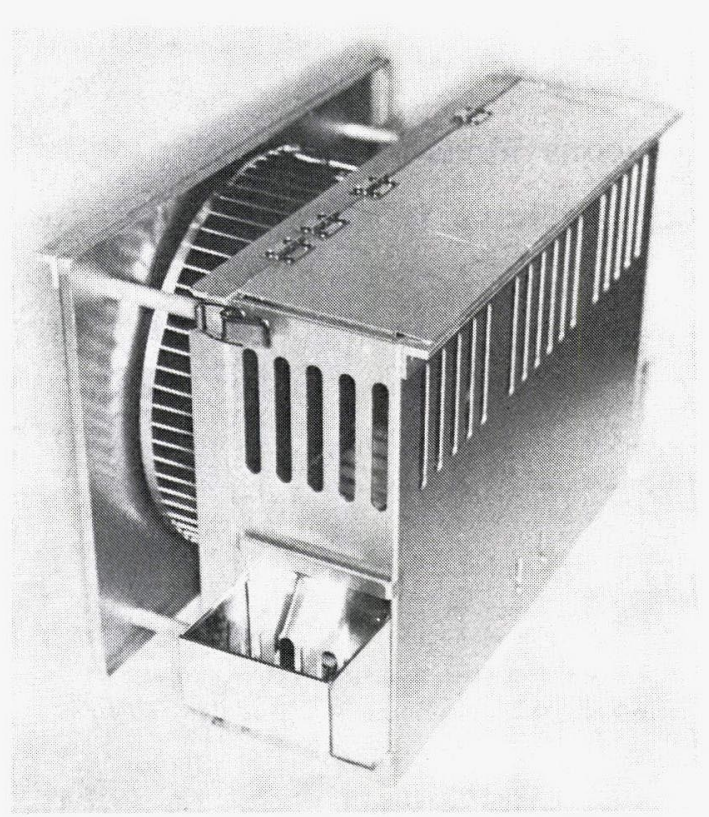

The running wheel basket was used to measur wheel-running activity and the tilting floor, ambulatory activity

Fig. 1. A new type of cage including a running wheel basket and tilting floor.

Counts of motor activity were collected every hour and analyzed by the time series method. Results were expressed as mean \pm S.E. Significance was assessed by Duncan's multiple test.

The changes in motor activity as measured by the three types of cages are presented in Fig. 3. Regardless of the type of cage used, a clear diurnal rhythm of motor activity cha-

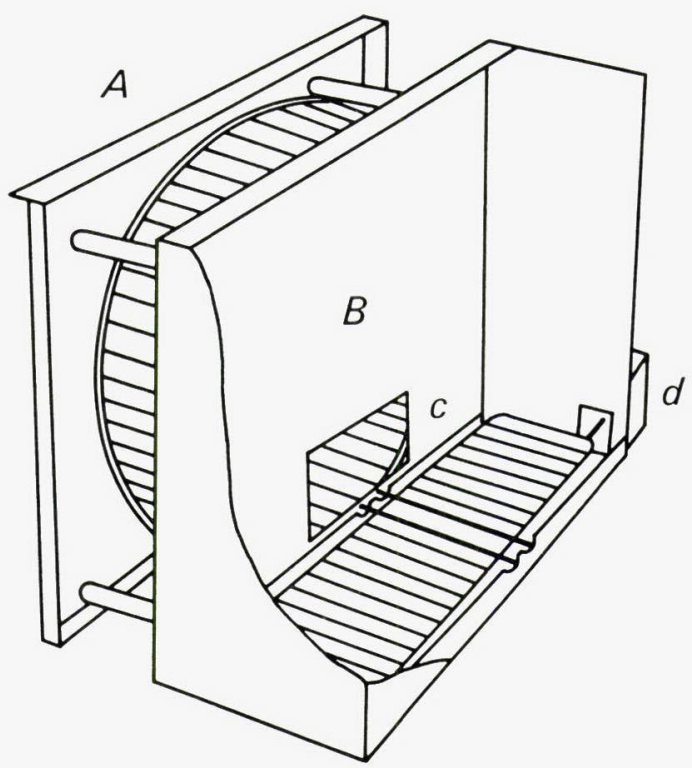

$A$ : Running wheel basket, $B$ : Tilting floor cage, $c$ : Entrance, $d$ : Sensor unit box.

Fig. 2. Illustration of the new type of cage.

racterizing nocturnal animals was observed.

From 77 to $98 \%$ of total activity was recorded during the dark periods. Total activity as measured by the three types of cages was stable throughout the experimental period, and there was no significant difference in total activity between the mean counts on the first and seventh days of the experiment. Total wheel-running activity measured using the new model on the 7th day of the experiment was found to be about $50 \%$ that estimated using

Table 1. Changes in total activity measured in three different types of cages.

\begin{tabular}{|c|c|c|c|c|c|c|c|c|c|}
\hline \multirow{2}{*}{ Cage } & \multirow{2}{*}{ Activity } & \multirow{2}{*}{$\begin{array}{l}\text { No. } \\
\text { of } \\
\text { rats }\end{array}$} & \multicolumn{7}{|c|}{ Days of experiment } \\
\hline & & & 1 & 2 & 3 & 4 & 5 & 6 & 7 \\
\hline \multirow[t]{2}{*}{ Amburo-drinko meter } & Ambulation & 5 & 559 & 544 & 561 & 601 & 622 & 601 & 557 \\
\hline & & & 70 & 64 & 100 & 116 & 86 & 80 & 51 \\
\hline \multirow[t]{4}{*}{ Running wheel } & Wheel-running & 5 & 5733 & 7216 & 6495 & 7447 & 8564 & 9194 & 9375 \\
\hline & & & 1799 & 2348 & 2189 & 2131 & 2764 & 3217 & 2932 \\
\hline & Ambulation & 5 & 222 & 283 & 274 & 283 & 355 & 317 & 266 \\
\hline & & & 35 & 44 & 41 & 28 & 50 & 112 & 75 \\
\hline \multirow[t]{2}{*}{ New model } & Wheel-running & 5 & 2303 & 3098 & 3499 & 3685 & 4959 & 4609 & 4026 \\
\hline & & & 480 & 445 & 779 & 1020 & 1588 & 2794 & 1436 \\
\hline
\end{tabular}

Upper values represent the mean of 5 determinations. Lower values represent $\pm \mathrm{S}$. E. Significance was assessed by Duncan's multiple range test between the mean on day 1 and others. 
Ambulo-drinko meter
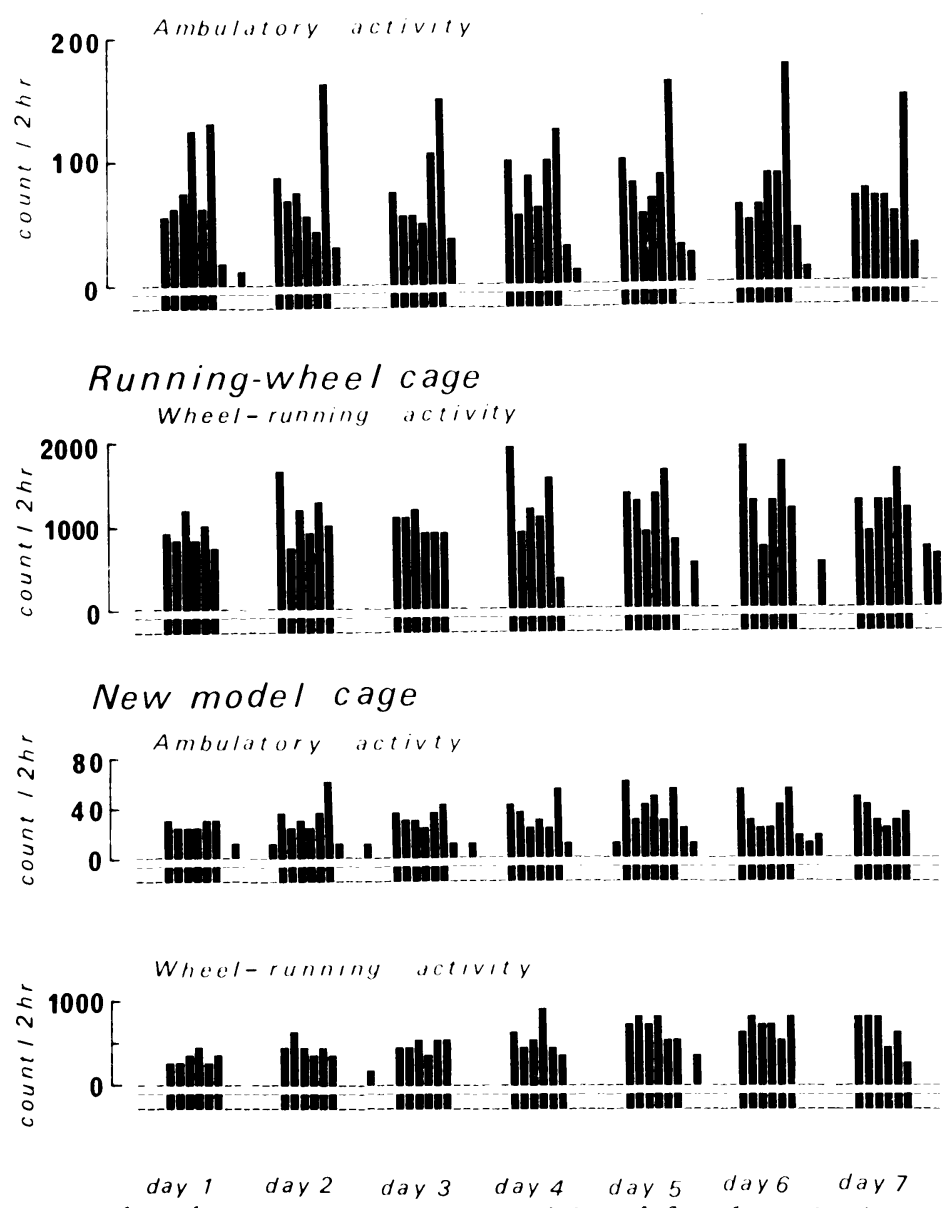

Each column represents mean activity of five determinations during a period of two hours. Dark bar indicates $12 \mathrm{hr}$ dark period and light bar, $12 \mathrm{hr}$ light period.

Fig. 3. Comparison of diurnal patterns of wheel-running and ambulatory activity as measured by three different types of cages.

the running wheel cage. Ambulatory activity as measured by the new model was also found to be about $50 \%$ of that estimated by the ambulo-drinko meter (Table 1). The diurnal rhythm of the wheel-running activity and that of the ambulatory activity as measured by the new cage were found to be synchronized.

From these results, it was concluded that both wheel-running and ambulatory activities are inherent behavior in the rat, because the total amount of these activities measured by the new cage decreased to $50 \%$ of those in standard cages. The present study demonstrated the possibility of simultaneous measurements of wheel-running and ambulatory activity by using the new type of cage.

\section{References}

[1] Borbely, A., and Huston, J. (1974). Physiol. Behave., 13, 795-802.

[2] Borbely, A. (1976). Brain Res., 114, 305-317.

[3] Festing, M. F. (1977). Labo. Anim., 11, 257-258.

[4] Kam, L. M., and Mobery, G. P. (1977). Physiol. Behave., 18, 213-217.

[5] Kurihara, H. (1980). Exp. Anim., 29, 327-333.

[6] Moberg, G. P., and Clark, C. R. (1976). Pharmacol. Biochem. Behav., 19, 617-619.

[ 7 ] Norton, S., Culver, B., and Mullemix, P. (1975). Behave. Biol., 15, 317-331.

[8] Peng, M. T., and Kang, M. (1984). Physiol. Behave., 33, 615-620.

[9] Peterson, G. M., Watking, W. B., and Moore, R. Y. (1980). Behave. Neurol. Biol., 29, 236-245.

[10] Tadokoro, S., Kurihara, H., Shirasaka, K., Alam, M. R., and Fujimoto, K. (1981). Jap. J. Neuropsychopharmacol., 3, 785-803. 
位置移動運動と走行運動の同時測定が可能な

新しいラット用運動測定ケージ

溝口順二・大滰恒夫

財 食品薬品安全センター秦野研究所

シーソー式の平面床と回転カゴとからなる新しいラッ 卜用自発運動測定ケージを作製した。このケージを用い て測定されたラットの位置移動運動量と走行運動量はそ れぞれ従来の平面ケージあるいは回転ケージで測定され た運動量の半分であった。新しいケージで測定された位
置移動運動と走行運動にも明確な日周リズムがみられ, また互いに同調していた。とのケージを用いるととによ りラットの位置移動運動と走行運動を同時に測定すると とが可能である。 